\title{
Dance and Work: The Aesthetic and Political Potential of Dance
}

BOJANA KUNST

\section{MOVEMENT BURSTING ON THE DIVIDING LINE}

The first film ever made captured the movements of the workers of the Lumière factory collectively surging through the factory gates upon leaving their workplace at the end of the day (1895). This same film also opened the performance 1 poor and one 0 by BADco., a Zagreb-based performance group ${ }^{1}$. This mass exodus from the factory not only marks the beginning of cinematic history, but also the problematic relation between cinema and labor, which is also explored in Harun Farocki's documentary and text of the same title Arbeiter Verlassen die Fabrik (1995). In his commentary of the documentary, Farocki states that the primary aim of the movie was to represent motion, using the mass exodus of the workers. According to Farocki, there may also have been signposts helping the workers coordinate their movements when exiting the factory. Interestingly, this invisible movement takes place along specific lines, those marking the difference between labor and leisure time, between the industrial process and the factory, on the one hand, and the private lives of the workers, on the other. The movements of the workers, their simultaneously organized and spontaneous dispersal into different directions is choreographically organized as movement and filmically framed by the line separating the enclosed industrial space from

1 BADco. is a collaborative performance collective based in Zagreb, Croatia (from 2000). The artistic core of the collective are Pravdan Devlahović, Ivana Ivković, Ana Kreitmeyer, Tomislav Medak, Goran Sergej Pristaš, Nikolina Pristaš and Zrinka Užbinec. 
private life, strictly rationalized procedures and so-called flexible leisure time. This is a line dividing dull work organization from leisure, when the workers can enjoy themselves, the mass organization of work and the atomized private lives of the workers. The dispersal of the workers renders their place of work invisible: the door to the factory is closed after their departure and the space, in which labor occurs, is left in darkness. Farocki mentions, that in the history of the cinema, the insides of factories were highlighted only when somebody wanted to leave, break it down or organize a strike. It was thus only featured when it became a space of conflict and was not only a dull, repetitive space to work in (cf. Farocki 2008: 1).

The whole performance 1 poor and one 0 revolves around that dividing line, always re-entering through that door, which is marked on stage by a simple crossbar. The performers repeatedly come through the gate, copying the movements of the workers in Lumière's movie. It almost seems as if they are in a motion picture experiment by Edward Muybridge, combining many short sequences of movement to give an impression of timing. In between these scenes, they discuss work-related issues: "What happens when you get tired? What happens when you leave work behind? When is the work we devote ourselves to exhausted? What comes after work? More work? What happens when there is no more work?" In the performance, these discussions clearly refer back to historical aspects of labor in the 20th century, especially to the gradual disappearance of that aforementioned dividing line. In this sense, they add another aspect to Farocki's observations. The place of work is no longer in darkness, but dispersed all over. It is not only a constituent part of leisure time, but intrinsically connected with its creative and transformative potential. By constantly repeating the movements from the 'first ever choreographed' movie, the performance becomes a collection of fragments and memories of movements, revealing that the first movie ever made arrived through a door, which today seems to have been taken off its hinges.

The movement of the workers is captured on a doorstep, which no longer exists; today there is no longer a dividing line between the movements of bodies subject to the rational organization of work and the dispersed atomization of society. Not only is the division between work and life being erased in postindustrial society; the essential qualities of life after work (imagination, autonomy, sociality, communication) have actually turned out to be at the core of contemporary labor. 


\section{Freedom of Singular Movement}

How is the disappearance of the dividing line between labor and leisure time related to contemporary dance and the conceptualization of movement? To answer this question, I would first like to briefly reflect on the appearance of contemporary forms of dance in the 20th century and in particular how their aesthetical and political potential is continuously being formed in a complex relationship with existing production modes. There are many issues where the organization of labor production and the conceptualization of movement converge in the history of contemporary dance (like scientific management, movement reforms, return to the natural body, etc.), however, these aspects are especially intriguing where they are intertwined with the political and aesthetical potential of dance.

It is a well-known fact that, from the beginning of the 20th century, new dance forms were experienced as something strongly connected to the potentials of the contemporary human being. Autonomous movement of the body opened new potentials of human experience and relationships, and had strong emancipatorial effects on the understanding of the future. To put it simply, the new, modern forms of dance (Isadora Duncan, Martha Graham, Mary Wigman, etc.) were perceived as breaking with old modes of perception. They provided the possibility of a new aesthetic experience, because of their intrinsic relationship between movement and freedom, which was presupposed in almost every attempt at movement reform. Even today, as Bojana Cvejić writes, "dance still works as a metaphor for going beyond contracts, systems, structures, as models of theorizing subjectivity, art, society, and politics" (Cvejić 2004: n.p.). According to her, this might be because "movement operates from the middle of things. Makes us step outside the pre-determination of points and positions. Expresses the potential of moving relations." (Id.) It thus seems that movement itself is intrinsically political, in the sense that it tackles relationality and the dynamics of expression, the potentiality of what it could or could not be. However, in that 'middle of things', movement also operates in the introductory image of the text, in the image where we see the workers exiting the factory. Movement is captured to disappear into the unknown future; nevertheless it came from a particular threshold, which frames the potential of moving relations in a very specific way. This potential is then developed outside the rationalized organization of labor; outside the Fordist structure of production, it is the potential of movement that springs from life without work. Alliances, relations, divisions exist outside the factory, in the space which not only becomes a political space, but also a field of autonomous aesthetic experience in which the crisis of the subject, new methods of kinaesthetic perception were developed and institutionalized through the history 
of art in the 20th century. Therefore, it is no coincidence that the dance reforms of the early 20th century appeared at the same point in time as the movement of the working body was being heavily rationalized in the Fordist factory: as the organization of production was based on a scientifically researched kinaesthetic experience, which instrumentalized the movements of the body to increase the efficiency of production. The (largely female) dance pioneers (Isadora Duncan, Loïe Fuller, Ruth St. Denis, Mary Wigman, Valentine du Saint Point, etc.) entered the stage at a time when the organizational model of labor had become omnipresent, when all forms of false, expressive, slow, still, unexpected, wrong, clumsy, personal, lazy, ineffective, imaginative, additional movement was eliminated from physical labor. The utopian relationship between movement and freedom in the early stages of contemporary dance and dance reform was therefore associated with a notion of abstract freedom, but expressed the potential of moving relationships outside the factory door. This was the freedom of another kinaesthetic experience, which would not yield to instrumentalization or be subject to work, but discover the inner potential of the body.

One of the ways of describing this experience is the discovery of the "natural body', which had less to do with resistance to the mechanization of contemporary life (whereby the term 'natural' wrongly implies that it is only about the difference between natural and artificial) and more with the discovery of a new universality, the natural sympathy of one body for another, as, for example, described by John Martin (cf. Martin 1990). The moving relations are no longer subordinated to dull routine and rationalization, but oscillate between the newly atomized society of capitalism and the new kinaesthetic subjects of industrialized western society.

I would like to argue that the appearance of dance reform and modern dance provided a movement and moving alternative to the kinaesthetic experience behind the factory door, which demanded the kinaesthetic sympathy of one body for another (and of course between body and machine) in order to create an efficient work process. We can even say that the feeling of modernity, contemporaneity of dancing, this disclosure of the kinaesthetic potentiality of body, was connected to the new kinaesthetic experience of leisure time, to this unknown and dynamic transversal outside work that is no longer subject to rational organization and the instrumentalization of movement. This is where we come to the core of the freedom implied in the emancipatory potential of dance. The conceptualization of movement in dance reform concerned the freedom of time without work, the discovery of the potential of leisure time, as opposed to the dull routine of movement during work. Movement expresses the potential of moving relationships within the creative time of the non-laboring subject. This can also be 
connected to the emerging consuming class, where movement reveals the unexpected, imagination, privacy, chance, flexibility, and discloses its expressive power. Here, time without work also becomes time for new aesthetic experiences. Contemporary dance had to develop new techniques, which could transform this freedom into language, develop the open virtuosity of the moving body rather than that of the instrumentalized product, and unleash spontaneity of movement as an aesthetic language rather then the scientific naturalization of movement. In this sense, the political and aesthetical potential of dance in the 20th century was strongly intertwined with the exit from the factory.

\section{Movement of Generality}

From this perspective, it is also interesting how popular imagination dealt with the work processes in the factory. Fordist production was often represented as synchronized group dancing, whereas dancing together functioned as an ornamental or critical representation of the subjugation of the worker's body to the industrialized and mechanistic processes in the factory. However, the only way to disturb this collective process came from the intervention of a singular body, from a body, which couldn't follow, was to clumsy, slow, dreamy, lazy or expressive, a body which took to much freedom to move, to express, or to achieve something. ${ }^{2}$ Exactly these physical qualities, which prevented the body from dancing with others, were understood as expressions of humanism, or even better - of uncontrollable and undisciplinable human nature. The singular kinaesthetic experience continuously resisted the tuning of the group and its subjugation to the rationalized social machine.

However - what, in 20th century capitalist societies, was an expression of freedom, became, in other ideological constellations, the sabotage of society in general, the representation of an obsolete individualism, which is not able to adjust itself to the new transformations of society. I especially have in mind here the communist countries of Europe, where the image of dancing together functions as a depiction of societies where the dividing line between factory and private life is ideologically erased. Communist systems adopted all movement reforms in the production and work process, but did so with a different underlying concept. The socialist defenders of Taylorism (which included Lenin himself) understood the scientific management of work as a tool for the management of a

2 A famous example is Charlie Chaplin as working at a conveyor belt in the movie Modern Times (1936). 
new society, where there would be no door between the factory and private life. In fact, there was a lot of discussion among Soviet communists and Russian avant-gardists on the hidden potentials of Taylorism and Fordism, which, in their opinion, went unnoticed by the Western capitalists, who had invented both. Lenin wrote that the Western (capitalist) implementation of Fordism, so it was believed, alienated the workers and developed an authoritarian method of organizing work. Socialist reformers and avant-gardists believed that the new methods of working together could transform society in general. The simultaneous movement of the workers was understood as a transgressive and transformative poetic form through which the development of the new society could materialize. Such was the conviction of A.K. Gastev, for example, one of the chief engineers and directors of the Central Institute of Labor in Moscow (he became its director in 1920). Gastev not only introduced Taylorist methods to the UdSSR and developed them further, but was also a famous poet, celebrating the new power of industrialized labor and the merging of the human being with the machine. In his poems, he developed rhythmical language to describe the new production process, where the workers would move and transform the entire historical era through their joint work.

"When the morning whistles resound over the workers' quarters, it is not at all a summons to slavery. It is the song of the future.

There was a time when we worked in poor houses and started our work at different hours of the morning.

And now, at eight in the morning, the whistles sound for a million men.

A million workers seize the hammers in the same moment.

Our first blows thunder in accord.

What is it that the whistles sing?

It is the morning hymn to unity." (Gastev/Bogdanov 1932: 357)

It is well known that the movement reforms of the Russian avant-garde (Meyerhold, Foregger, and partially - in the European context - also those of Laban) were heavily influenced by the new production processes, by their abstraction and rationalization. The movement reformers sought to abstract the body away from its interiority and develop an effective gestural language. In other words, they wanted to develop new kinaesthetic dynamics through the efficient use of gesture and a sharp instrumentalization of the body. Meyerhold, for example, began to rationalize the apparatus of movement; the actor's body also became a model for a general optimization of movement. Even though his work was closely connected to Gastev's and Taylor's utilitarian models of production, the me- 
thods he used, writes Gerald Raunig, went in another direction: he also wanted to denaturalize theatre (cf. Raunig 2010). Contrary to the psychology of a plot and the presence of an empathetic audience, and also contrary to the singular kinaesthetic experience of the dancing body, which was developing as an autonomous aesthetic language in the West (especially in North America), movement in the concepts of the Russian avant-garde (or the important components of biomechanics) consisted of the rhythm of language and the rhythm of physical movement, of postures and gestures arising from the collective rhythms, which coordinated the movements of the body and that of bodies with one another.

What we observe here are thus two different relationships between the conceptualization of movement and the organization of production (labor itself) in the 20th century. In so-called Western societies, which could be more accurately described as 'capitalist' societies, we see processes of naturalizing movement, which opposed the instrumental use of the laboring body and the rational organization of society. Such naturalization of movement corresponds with the discovery of the singular subject, an individual with desires and transversal and transgressive dynamic movement outside the modes of production (metaphorically speaking outside the factory gates). Most of the time, this individual is conceived as constantly in motion, in the throes of continuous creativity and possessing an autonomous aesthetic language: an individual, who cannot not dance. ${ }^{3}$ On the other side, there is the proposition of coming through the factory gates - the idea that the modes of production can be intertwined with the transformation of society in general.

The movement reforms of the historical avant-gardes erased the door between work and private life, and revealed themselves as kinaesthetic constructions of larger future worlds. In the movement reforms of the Russian and European avant-gardes (especially the Futurists), a fascination with industrialized means of production led to experiments in denaturalizing movement. The body became a field of experimentation for future social transformation and for understanding a new commonality. Here dance and the production process paved the way to exploring a new generality of people: a generality that comes before any individualization, a sense of the political generality of the future, which has yet to come. Unfortunately, the discovery of the movement of this generality was an enormous failure. It quickly lost its emancipatory, political potential and became a totalitarian unity in the communist regime. Where a clumsy, still, expressive,

3 The aspects of kinetic ideologies of modernity are analysed in André Lepecki: Exhausting Dance: Performance and the Politics of Movement (2006). 
lazy, dreamy, everyday, marginal movement is possibly perceived in capitalist societies as the intervention of a liberated singularity, in the communist regimes, this kind of movement sabotaged the whole social machine. In their utopian pursuit of the future, these societies erased everything that radically existed in the present, because of the cynical belief that the future had already arrived. It therefore comes as no surprise that the communist regimes actually celebrated the most conservative and disciplinary forms of dancing, such as mass gatherings or the authoritarian institution of ballet.

This comparison between two concepts of movement - one that situates the political potential of dance in the movement of a singularity and the other in the discovery of a new (political) generality of the people (especially if we stay with avant-garde concepts) - leads, from today's perspective, to a very interesting observation. We are living in an age that is erasing the doors between factory and leisure time, in a time where individual potential and singular creativity is central to production. The movement of this working rhythm is very different from the description in Gastev's poem, which celebrates exactly the same disappearance of the factory doors. Instead of a synchronized totality of work as a new transformation of society, represented through the image of 'everybody starting at the same time' as described in his poem, today the new transformation of society is taking place with disharmonious working rhythms and flexible working hours, with individualized and displaced work. The factory whistle is replaced by selfimposed and silent deadlines, which drive people to multiple simultaneous and interconnected work and living activities. The movement of the individual, which throughout the 20th century was celebrated as the discovery of the potential of freedom stands at the centre of appropriation, of the exploitation of its affective, linguistic and desirable aspects. Today we are forced to dance in virtuous and conceptual diachronicity when producing; to change places, time, and identities quickly and with only short (but hardly ever destructive) outbursts of crisis. This is the new universality of the post-industrial world and its mode of production.

\section{The Disappearance of the Gates AND ITS CONSEQUENCES}

This argument leads me to a cartoon from 1980 by the well-known American cartoonist and satirist Dr. Seuss (Theodor Seuss Geisel) - Pontoffel Pock Where Are You? In this cartoon we again find a satirical image of workers dancing together; the working process in a pickle factory is actually depicted as a harmo- 
nious musical. However, one of the new workers, Pontoffel Pock, is quite a looser. He is clumsy and always disrupting the process, poor and unhappy. Clumsy by nature and dreamy by heart, he tries to push and pull the machine as the other workers do, but in his eagerness to do it well, he destroys the whole factory and is dismissed from the factory in disgrace. Wallowing in self-pity, he is approached by an angel, who presents himself as a representative of a global corporation with branches all over the world. Because, as the corporative angel tells him, his lifestyle is pitiable, he is offered a wondrous piano. All that Pontoffel Pock needs to do is to play a few notes, push the bottom of the piano and he can fly to any exotic destination in the world to experience beautiful and exciting adventures. All that is required is a little tune; with just a little bit of virtuosity, he can fly away into an unknown and exciting future. But again Pontoffel Pock is unable to behave right. He has trouble with unpredictable gestures and movements, with his body, which desires too much and is 'always in the wrong place'. He cannot simply enjoy and be spontaneous. Instead he destroys all social relations with his ill-timed actions. This continues until he finds the love of his life (an Arab princess) and gets one more try at a pickle factory.

The cartoon offers a very good description of the shift that occurred at the beginning of the 1970s, a shift, which can be today be described with the terms post-industrialism or post-Fordism, especially when speaking about modes of working. The main characteristics of this shift have been deep changes in the organization of production and the role of labor, which influences social relations in general. Creative, linguistic and affective labor has become central to production. Labor is no longer organized in an instrumental and rationalized way, behind factory doors, but has become part of the production of social life and relationships among people. What was previously excluded from the de-naturalized movement of the Fordist machine is today at the centre of production: creative, spontaneous, expressive and inventive movement. Contemporary production structures demand creative and capable individuals. Their constant movement and dynamism have become the promise of economic value.

The image of production as dancing together is today an anachronistic one, due also to the ineffectiveness of its social critique. Today Fordist machinery has moved out of our range of vision to countries with a cheap labor force, where there is no escape into leisure time, but only the brutal exploitation of life in all its aspects. The contemporary post-Fordist worker is no longer included in the rationalized machine, but is instead part of affective and flexible networks, with his or her own potential for sale. Italian philosopher Paolo Virno, describes the qualities required of a post-Fordist worker, by saying that such qualities are never qualities 
"[...] regarding professional expertise or technical requirements. On the contrary, what is required is the ability to anticipate unexpected opportunities and coincidences, to seize chances that present themselves, to move with the world. These are not skills people learn at the workplace. Nowadays, workers learn such required abilities by living in a big city, by gaining aesthetic experiences, having social relationships, creating networks: all things workers learn specifically outside the workplace, in real life in a contemporary big city." (Virno 2009: n.p.)

In other words, production today is experienced as something spontaneous and flexible. The process of work is always "subject to our own initiative" (id.). In the process of work, "I need to be granted a certain degree of autonomy in order to be exploited" (id.). It is from this perspective that we can also understand another image of dancing together, which has begun appearing over the past years in countries belonging to the post-industrial world: huge flash mobs organized by corporations and television companies. On the surface, it seems that these dances celebrate spontaneity and the emotional strength of human relations. However what really constitutes them are celebrations of commercialized joy and spectacular togetherness.

\section{Dance AND the Abstraction of Work}

If we agree with Virno's observation, then it is necessary to rethink the consequences of such changes in the modes of working for the conceptualization of contemporary dance, especially where I have claimed that dance discovers its political and aesthetic potentiality in relationship to the production process. What are the consequences for contemporary dance with these changes in mind? What could the disappearance of the differentiation between work and non-work mean for the relationship between dance and freedom, which was always somehow the basis of thinking about dance reform in the 20th century?

First, it should not be overlooked, that the relationship between dance and freedom no longer has anything to do with resistance to rigid and disciplinary modes of production. Unexpected, non-hierarchical structures, affectivity and linguistic/physical expression have entered post-industrial production and represent the core of post-Fordism as the new organization of the production processes we are living in. The autonomy of creativity and aesthetic experience, which was so important when resistance to the rationalization of labor first emerged, now represents an important source of producing value. What we thus observe are relationships between contemporary dance and new modes of pro- 
duction, in which movement and constant flexibility play a central role, together with individual expression and spontaneous creativity. Today subjugation is composed of continuous movement, a flexibility of relationships, signs, connections, gestures, bodies - continuous dispersion outside the factory gates with the intent to produce (and spend) even more. Production today encourages constant transformation and the crisis of the singular subject, with the intention of capturing outbursts of creativity and translating them into value. Production encourages ceaseless collaboration, which must be temporary, but not too affective, otherwise it can become ill-timed and destructive.

If this is truly the case, then we must ask ourselves what it exactly is that we do, when we work, or more precisely, when we work with dance. The political potential of dance is not related to the space outside of work, where the body is free to move and disclose its potential of being in time and space, but it must be put into dialogue with the flexible production modes and immateriality of contemporary work. It is common knowledge that the production of contemporary dance is today becoming more flexible through continuous travel. Where the exchange of forever-young and forever-experimental performances (a kind of cheap labor force for more and more globalized performance markets) goes hand in hand with spectacular shows. How collaboration is encouraged for collaboration's sake. How the continuous traveling movement of the labor force is unavoidable. However it is often forgotten that dance and movement have their own materiality, not only that of the body, but also of time and space, which is not abstract, rushed into the spectral kinetic flow, but can also be grasped, located, stuck, rough and ill-timed. This materiality resists the contemporaneity of time and in some ways sabotages the spectral appearance of the 'now' and gives another rhythm to the flow of time. This materiality can be also be brought into relationship with the materiality of work in general and in this sense, dance is again very close to questions of labor.

Thus dance is not close to questions of work, because of its ability to function as a representation of work, an image of the working process, but because it is work in terms of its material rhythms, efforts, in how movement inhabits space and time. It is work in the sense of how bodies distribute themselves in space and time, how they relate to each other and how they spend and expand their energies. The political potential of dance therefore does not have to be sought in an abstract or democratic idea of freedom and the infinite potential of movement, but in the ways how dance is deeply intertwined with the power and exhaustion of work, with its virtuosity and failure, dependence and autonomy. In this sense, dance practice over the last decades has stressed its own ontological propositions (such as dance equals movement, production and collaboration in dance, the re- 
lationship between dance and theory) (cf. Lepecki 2006; Kunst 2009; Franko 1995). These are propositions, which all open up dance practice to being aware of the relationship between dance and work. If dance is work (and not something opposite to it, dance freed from the materiality of it), then the political potential of dance can also be understood as an interesting repetition or replacement of the avant-garde gesture: what would that proposition - dance as work - mean for a future society? Is it possible to discover an alternative to continuous movement and speed, to the flexibility of bodies and spaces, to the dispersion of energy and the power of the bodies collected together only for advertisement purposes and massive spectacles? One such answer could be that dance can reveal how kinetic sensibilities not only flow, but open up caesuras, antagonisms and unbridgeable differences. In this sense, many dance performances of the last decade have requestioned the relationship between movement and dance and broadened the notion of choreography. Another answer could be that dance with its materiality can resist the abstract notion of labor and reveal the problematic relationship between the abstract new modes of labor and the bodies themselves. New modes of labor have tremendous power over the body, especially because they are increasingly erasing every representable and imaginable generality of the body. The dancing body is no longer resisting the dull conditions of work in search of a new society outside of work, but it does have the power to disclose how the materiality of bodies distributed in the time and space can change the way we live and work together. It can use this politically and aesthetically transgressive line between work and non-work to open up chances for a future society.

\section{REFERENCES}

Cvejić, Bojana (2004): "How open are you open? Pre-sentiments, pre-conceptions, pro-jections", http://www.sarma.be/text.asp?id=1113 (June 21, 2010).

Farocki, Harun (2008): "Workers Leaving the Factory", in: 1 poor and one 0 (= programme of the performance), Zagreb: BADco.

Franko, Mark (1995): Dancing Modernism, Performing Politics, Bloomington: Indiana University Press.

Gastev, A.K. (1932): "The Song of the Workers Blow", in: Aleksandr Bogdanov, Proletarian Poetry, The Labour Monthly, June 1932, pp. 357-362.

Kunst, Bojana (2009): Prognosis on Collaboration, in: Gabriele Brandstetter et al. (eds.), Prognosen über Bewegungen, Berlin: B-Books, pp. 336-347.

Lepecki, André (2006): Exhausting Dance: Performance and the Politics of Movement, Routledge: Champan and Hall. 
Martin, John (1990): The Modern Dance, Hightstown, NY: Dance Horizons.

Raunig, Gerald (2010): A Thousand Machines: A Concise Philosophy of the Machine as a Social Movement, trans. by Aileen Derieg (= Semiotext[e]) Cambridge, MA: MIT Press.

Virno, Paolo (2009): "The Dismesure of Art", in: Open 17, A Precarious Existence, Vulnerability in the Public Domain, http://www.skor.nl/article-4178en.html (June 21, 2010).

\section{FILMS}

Arbeiter verlassen die Fabrik (1995) (DE, D: Harun Farocki)

Modern Times (1936) (USA, D: Charles Chaplin)

Pontoffel Pock, Where Are You (1980) (USA, D: Gerard Baldwin) 
